\title{
Synthesis, spectroscopic characterization and DFT calculations on [4-(sulfonylazide)phenyl]-1-azide
}

\author{
Abbas Teimouri $^{\text {a }}$, Alireza Najafi Chermahini, ${ }^{* b}$ and Mohammad Emamic \\ ${ }^{a}$ Payame Noor University, Isfahan, Iran \\ ${ }^{b}$ Department of Science, Faculty of Chemistry, Yasouj University, Yasouj, Iran \\ ${ }^{c}$ Department of Chemistry, Shahid Beheshti University, Tehran, Iran \\ E-mail:najafi@mail.yu.ac.ir
}

Dedicated to Professor Hossein A. Dabbagh

\begin{abstract}
The title compound, [4-(sulfonyazide) phenyl]-1-azide has been synthesized and characterized by elemental analysis, IR, UV-Vis, Mass and NMR. Density functional theory (DFT) calculations have been carried out for the title compound by performing HF and DFT levels of theory using the standard $6-31 G^{*}$ basis set. The calculated results show that the predicted geometry can well reproduce the structural parameters. Predicted vibrational frequencies have been assigned and compared with experimental IR spectra and they support each other. The theoretical electronic absorption spectra have been calculated by using CIS, TD-DFT, ZINDO methods. ${ }^{13} \mathrm{C}$ and ${ }^{1} \mathrm{H}$ NMR of the title compound have been calculated by means of B3LYP density functional method with $6-31 G^{*}$ basis set. Comparison between the experimental and the theoretical results indicates that density functional B3LYP method is able to provide satisfactory results for predicting NMR properties. On the basis of vibrational analyses, the thermodynamic properties of the title compound at different temperatures have been calculated.
\end{abstract}

Keywords: Sulfonyl azide, vibrational frequency, electronic absorption spectra, NMR, DFT, $a b$ initio

\section{Introduction}

Organic azides are versatile starting materials for the synthesis of a variety of nitrogencontaining compounds that attracts the attention of both the organic and inorganic chemists. 1, 3Dipolar cycloadditions with the participation of organic azides have been turned into a valuable tool for the construction of heterocyclic compounds. ${ }^{1}$ The addition of 1, 3-dipolar species to unsaturated molecules for the synthesis of five-membered rings is a classical reaction in organic 
chemistry. These cycloadditions have been utilized for the preparation of compounds that are of fundamental importance in diverse fields of chemistry. ${ }^{2}$ The use of 1,3-benzenedisulfonyl azide as a cross-linking agent in polyolefins and polyolefin containing blends is covered in a number of patents and publications. ${ }^{3-7}$

Inorganic chemists consider organic azides as readily accessible substrates for the preparation of nitrene (imido) complexes. ${ }^{8}$ Recently, the first successful isolation of complexes incorporating aryl, alkyl and arenesulfonyl azides as ligands has allowed us to take an insight into the chemical and structural features of complexes which have emerged so far only as elusive intermediates of organometallic reactions. ${ }^{9}$ Due to the practical and theoretical importance of organic azides, a variety of experimental methods and techniques have been used for their structural characterisation. These include $\mathrm{IR}^{5}, \mathrm{NMR}^{10}$ and microwave ${ }^{11}$ spectroscopy, electron diffraction ${ }^{12}$, mass spectrometry ${ }^{13}$ and ab initio quantum chemical calculations. ${ }^{14}$

Disulfonyl azides have earlier been shown to be effective agents for cross-linking of various hydrocarbon polymers. ${ }^{3-6,15-17}$ The cross-linking reaction between hydrocarbons and sulfonyl azides isbelieved not to involve radicals, but to occur by an insertion reaction. Disulfonyl azides are, therefore, capable of cross-linking polyolefins with tertiary carbon atoms, such as polypropylene and polyethylene copolymers. As a part of our ongoing studies on sulfonyl azides $^{18-21}$, in this paper we consider the synthesis and characterization of [4(Sulfonylazide)phenyl]-1-azide (Figure 1).

\section{Results and Discussion}

The general route for the synthesis of [4-(Sulfonylazide)phenyl]-1-azide is shown on Scheme 1. The optimized structure parameters of this compound calculated by ab initio and DFT/B3LYP levels with the $6-31 \mathrm{G}^{*}$ basis set are listed in Table 1 . The aim of this study is to give optimal molecular geometry and vibrational modes of title compound.

The optimized configurations are shown in Figure 1. Since the crystal structure of this compound is not available, the optimized structure can be only being compared with other similar systems for which the configurations have been optimized. ${ }^{22}$ For example, the optimized bond lengths of $\mathrm{C}-\mathrm{C}$ in phenyl ring fall in the range from 1.37783-1.39204 $\AA$ for $\mathrm{HF} / 6-31 \mathrm{G}^{*}$ method and 1.38901-1.40271 $\AA$ for B3LYP/6-31G* method, which are in good agreement with a similar molecular structure, (phenyl ring with arensulfonyl group) $1.385-1.400 \AA .^{22}$ The optimized $\mathrm{C}_{\text {ring }}-\mathrm{N}$ bond length by two methods are $1.40669 \AA$ for HF/6-31G* method and $1.41179 \AA$ for B3LYP/6-31G* method, which is slightly shorter than that in compound with a similar molecular structure. ${ }^{23}$ For the bond of $\mathrm{C}_{\text {ring }}-\mathrm{S}$, the optimized lengths (see Table 1) are slightly shorter than that in compound with a similar molecular structure (1.75906 $\AA$ for HF/ 6$31 \mathrm{G}^{*}$ method and $1.78177 \AA$ for B3LYP/ 6-31G* method). ${ }^{23}$ Based on above comparison, although there are some differences between our values and the literature data, the optimized 
structural parameters can well reproduce the literature ones and they are the bases for thereafter discussion.

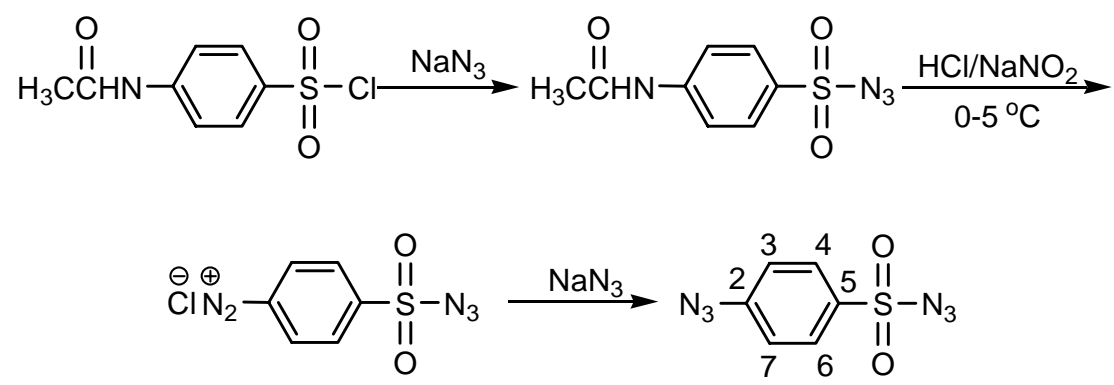

Scheme 1. Chemical structure of prepared compound.

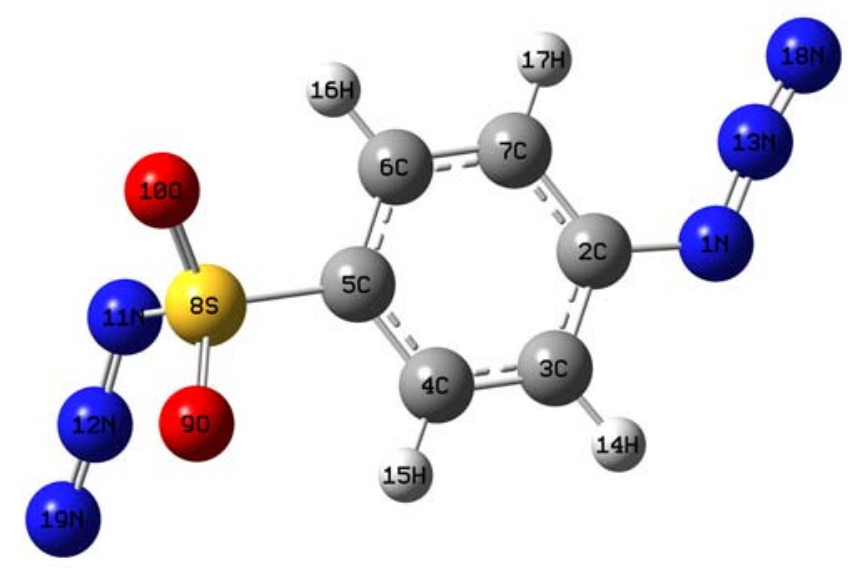

Figure 1. The structure title compound, optimization has been performed by the B3LYP/6-31G* method.

Table 1. Selected bond distances $(\AA)$, bond angles $\left(^{\circ}\right)$ and torsional angles $\left(^{\circ}\right)$ of the title compound optimized

\begin{tabular}{lcc}
\hline Entry & $\mathrm{HF} / 6-31 \mathrm{G}^{*}$ & $\mathrm{~B} 3 \mathrm{LYP} / 6-31 \mathrm{G}^{*}$ \\
\hline Bond lengths $(\AA)$ & & \\
\hline N1-C2 & 1.40669 & 1.41179 \\
C2-C3 & 1.39204 & 1.40271 \\
C3-H14 & 1.07312 & 1.08466 \\
C3-C4 & 1.37783 & 1.38901 \\
C4-H15 & 1.07335 & 1.08455 \\
C4-C5 & 1.38921 & 1.39798 \\
C5-C6 & 1.38589 & 1.3975 \\
C6-H16 & 1.07315 & 1.08467 \\
\hline
\end{tabular}


Table 1. Continued

\begin{tabular}{lcc}
\hline C6-C7 & 1.3809 & 1.38949 \\
C7-H17 & 1.07441 & 1.08602 \\
C5-S & 1.75906 & 1.78177 \\
S-N11 & 1.68627 & 1.67392 \\
N11-N12 & 1.24969 & 1.24465 \\
N12-N19 & 1.0913 & 1.13647 \\
N1-N13 & 1.23923 & 1.24115 \\
N13-N18 & 1.09662 & 1.13885 \\
\hline Bond angles $\left(^{\circ}\right)$ & & \\
\hline N1-N13-N18 & 174.10801 & 173.16741 \\
N11-N12-N19 & 174.85651 & 174.82158 \\
N1-N13-C2 & 34.32323 & 33.011539 \\
N1-C2-C3 & 115.19545 & 115.6895 \\
N1-C2-C7 & 124.77824 & 124.02703 \\
C5-S-O10 & 32.3188 & 33.00977 \\
C5-S-O9 & 108.51088 & 109.08105 \\
O9-S-N11 & 107.64464 & 108.17043 \\
O10-S-N11 & 104.65159 & 103.79028 \\
\hline Dihedral angles $\left(^{\circ}\right)$ & & \\
\hline N1-N13-N18-C2 & -179.88912 & -179.96236 \\
N1-C2-C3-H14 & 0.49266 & 0.38998 \\
N1-C2-C7-H17 & -0.32399 & -0.28545 \\
C5-S-O9-O10 & 127.28323 & 129.36575 \\
O10-S-O9-N11 & 120.7313 & 120.73835 \\
O9-S-N11-N12 & -15.46006 & -10.85129 \\
N19-N12-N11-S & -174.6201 & -174.4292 \\
S-C5-C4-H15 & -1.42916 & -1.08098 \\
S-C5-C6-H16 & 1.07636 & 0.93622 \\
\hline & & \\
\hline
\end{tabular}

\section{Vibrational frequency}

The observed experimental FT-IR spectra and theoretically predicted IR spectra are shown in Figures 2-4. The vibrational frequency and approximate description of each normal mode obtained using HF and DFT/B3LYP methods with 6-31G* basis set are given for this compound in Table 2.

In our study, vibrational frequencies calculated at B3LYP/6-31G* level were scaled by 0.96 and those calculated at HF/6-31G* level were scaled by $0.89 .{ }^{20}$ Gauss-view program ${ }^{24}$ was used to assign the calculated harmonic frequencies. On the basis of the comparison between calculated 
and experimental results, assignments of fundamental modes were examined. The assignment of the experimental frequencies are based on the observed band frequencies in the infrared spectra of this species confirmed by establishing one to one correlation between observed and theoretically calculated frequencies.

The calculated frequencies are slightly higher than the observed values for the majority of the normal modes. Two factors may be responsible for the discrepancies between the experimental and computed spectra of this compound. The first is caused by the environment and the second reason for these discrepancies is the fact that the experimental value is an anharmonic frequency while the calculated value is a harmonic frequency. ${ }^{25}$ A linearity between the experimental and calculated wave numbers (i.e. for the whole spectral range considered), can be estimated by plotting the calculated versus experimental wave numbers (Figure 5). The values of correlation coefficients provide good linearity between the calculated and experimental wave numbers (correlation coefficients of 0.899-0.999). The benzene ring modes predominantly involve $\mathrm{C}-\mathrm{C}$ bonds and the vibrational frequency is associated with $\mathrm{C}-\mathrm{C}$ stretching modes of carbon skeleton. The $\mathrm{C}-\mathrm{C}$ stretching modes, known as semi-circle stretching, predicted at $1510-1660 \mathrm{~cm}^{-1}$ is in excellent agreement with experimental observation of FT-IR value at $1520-1640 \mathrm{~cm}^{-1}$. The ring breathing mode at $630 \mathrm{~cm}^{-1}$ coincides satisfactorily with a very weak band at $670 \mathrm{~cm}^{-1}{ }^{26}$

The aromatic structure shows the presence of $\mathrm{C}-\mathrm{H}$ stretching vibrations in the region 2900 $3150 \mathrm{~cm}^{-1}$ which is the characteristic region for the ready identification of the $\mathrm{C}-\mathrm{H}$ stretching vibrations. In this region, the bands are not affected, appreciably by the nature of the substituents. The vibrations in the this region $\left(2900-3150 \mathrm{~cm}^{-1}\right)$ are in agreement with experimental assignment $2870-3130 \mathrm{~cm}^{-1} \cdot 27,28$ The out-of-plane bending of $\mathrm{C}-\mathrm{H}$ predicted region of $1040-1060 \mathrm{~cm}^{-1}$ at $\mathrm{B} 3 \mathrm{LYP} / 6-31 \mathrm{G}^{*}$, while the calculations at $\mathrm{HF}$ level give the frequency values of $1050-1070 \mathrm{~cm}^{-1}$, slightly on the higher side of expected region.

The calculations also show that the $\pi(\mathrm{CH})$ vibrations are not pure and contain significant contributions of other modes $(v(\mathrm{SN})$ and $\pi(\mathrm{CN}))$. The stretching $v(\mathrm{C}-\mathrm{N})$ vibrations could be observed for the compound studied in a broad energy range, depending on the $\pi$-bonding nature of the $\mathrm{C}-\mathrm{N}$ bond. Single $\sigma(\mathrm{C}-\mathrm{N})$ bonding appears, for the example, in the azoaromatic compounds.

The S-N stretching vibration exhibits a moderate band in the region $1010-1020 \mathrm{~cm}^{-1}$, the band observed at this region is not pure $v(\mathrm{SN})$ vibration and contains a significant contribution of $\pi(\mathrm{CH})$ mode. The observed bands $1320-1470$ and $1100-1120 \mathrm{~cm}^{-1}$ were assigned to the $v\left(\mathrm{SO}_{2}\right)$ asym. and $v\left(\mathrm{SO}_{2}\right)$ sym. Modes, respectively. The bands at $510-530 \mathrm{~cm}^{-1}$ were assigned to, the $\mathrm{SO}_{2}$ scissors and $\mathrm{SO}_{2}$ wagging vibration, and have partly overlapped in this region, calculations show that $\omega\left(\mathrm{SO}_{2}\right)$ vibration contains a considerable contribution with $\pi$ ring. ${ }^{29}$ The major bands $\left(630-890 \mathrm{~cm}^{-1}\right.$ region) relate to $\mathrm{S}-\mathrm{C}$ stretch. 


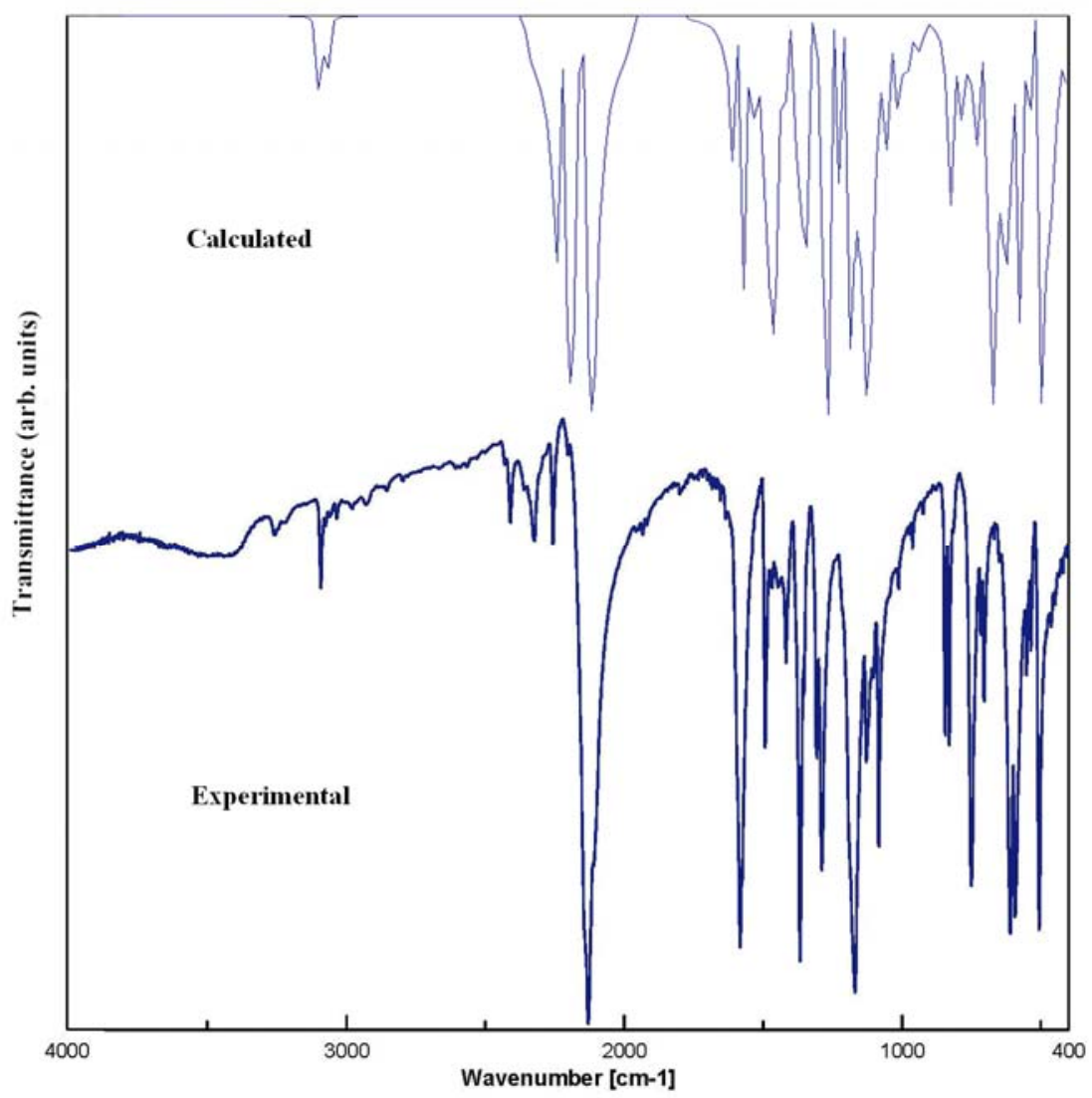

Figure 2. The calculated and experimental FTIR spectra of [4-(Sulfonylazide)phenyl]-1-azide.

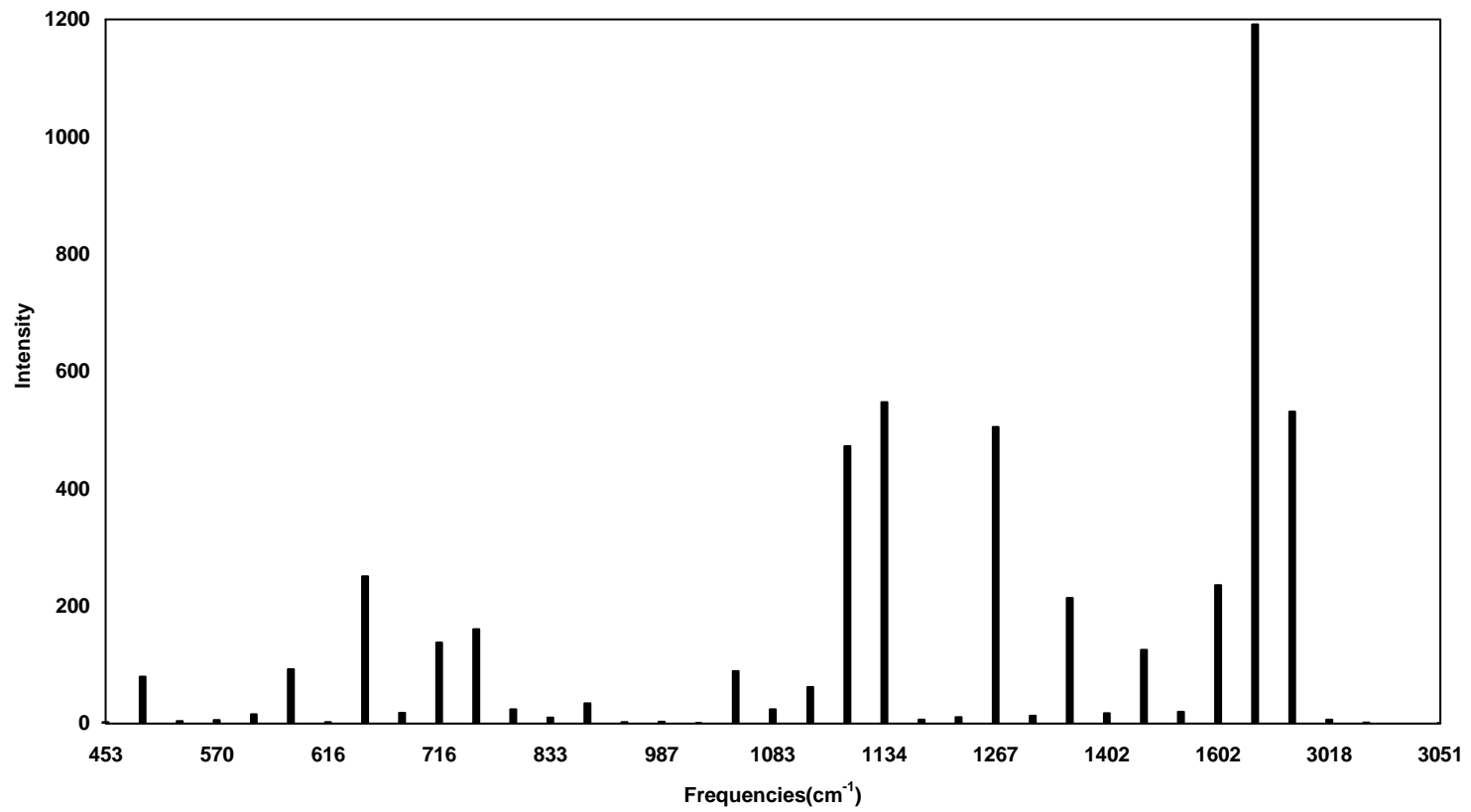

Figure 3. HF/6-31G* level for the compound. 


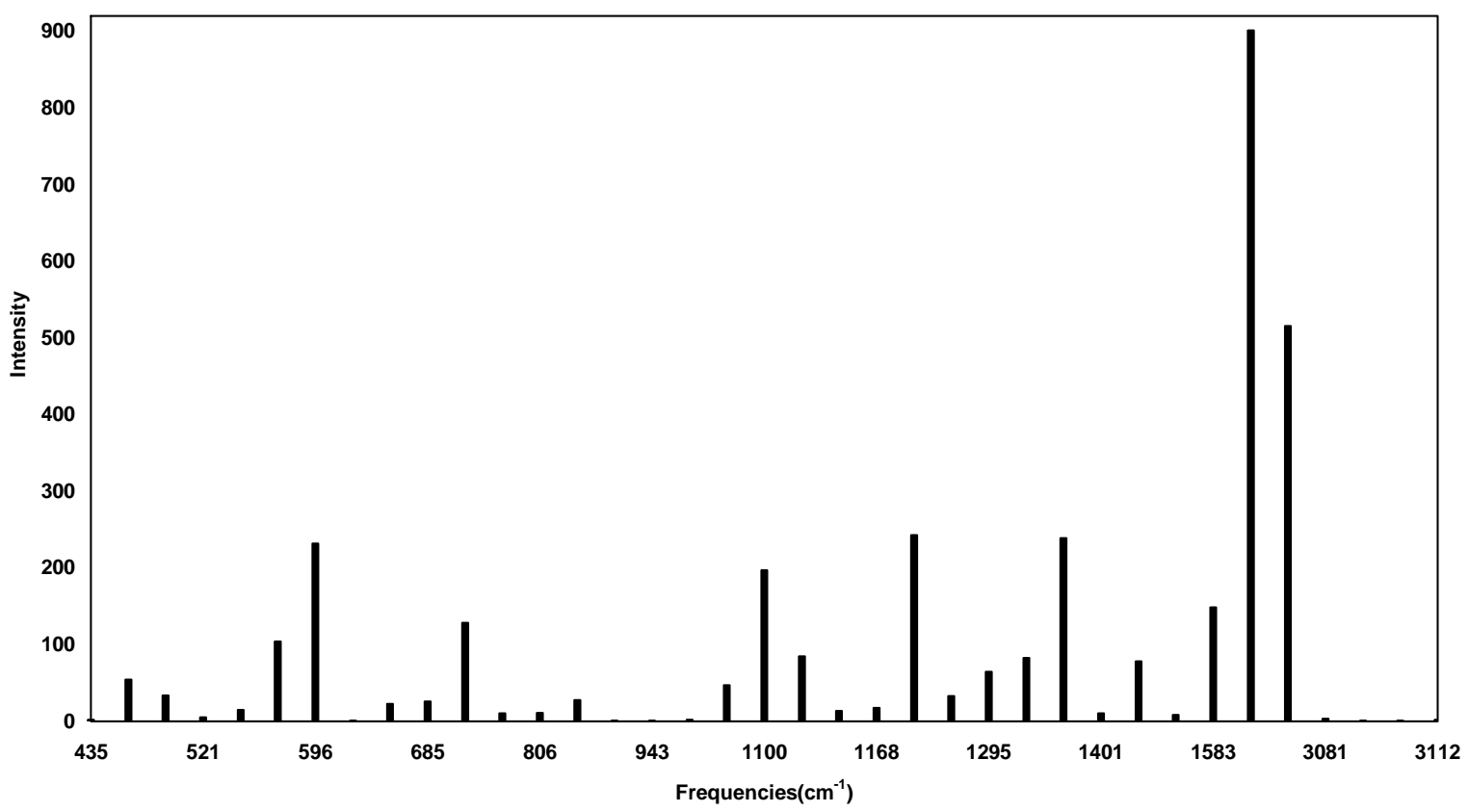

Figure 4. B3LYP/6-31G* level for the title compound.

Table 2. Comparison of the observed and calculated vibrational spectra of the title compound

\begin{tabular}{ccccc}
\hline & HF $(\mathrm{I})$ & B3LYP $(\mathrm{I})$ & Exp. & Assignment \\
\hline 1 & $3051(1.2063)$ & $3112(1.7319)$ & 3092 & $v(\mathrm{CH})$ \\
2 & $3047(0.4192)$ & $3107(0.7251)$ & 3074 & $v(\mathrm{CH})$ \\
3 & $3035(1.5172)$ & $3099(0.7479)$ & 3062 & $v(\mathrm{CH})$ \\
4 & $3018(6.5752)$ & $3081(3.0601)$ & 3035 & $v(\mathrm{CH})$ \\
5 & $2289(531.938)$ & $2183(515.566)$ & 2203 & $\mathrm{~N}_{3}$ \\
6 & $2242(1191.76)$ & $2171(900.958)$ & 2129 & $\mathrm{~N}_{3}$ \\
7 & $1602(235.726)$ & $1583(148.69)$ & 1582 & $v_{\text {ring }}$ \\
8 & $1575(20.0382)$ & $1560(8.5409)$ & 1522 & $\mathrm{C}=\mathrm{N}$ \\
9 & $1494(125.779)$ & $1477(78.3158)$ & 1456 & $v_{\text {ring }}$ \\
10 & $1402(17.3911)$ & $1401(10.1777)$ & 1418 & $v_{\text {ring }}$ \\
11 & $1329(214.065)$ & $1325(239.152)$ & 1366 & $v_{\text {sym. }}\left(\mathrm{N}_{3}\right)$ \\
12 & $1300(13.3605)$ & $1310(82.454)$ & 1306 & $\mathrm{v}_{\text {asym. }}(\mathrm{SO} 2)$ \\
13 & $1267(505.725)$ & $1295(64.674)$ & 1288 & $\mathrm{v}(\mathrm{CN})$ \\
14 & $1175(11.0434)$ & $1286(32.9505)$ & 1169 & $\mathrm{v}(\mathrm{CN})$ \\
15 & $1161(6.4951)$ & $1221(242.656)$ & 1129 & $\pi(\mathrm{CH})$ \\
16 & $1134(547.951)$ & $1168(17.3495)$ & 1109 & $\pi(\mathrm{CH})$ \\
17 & $1131(472.553)$ & $1122(13.6459)$ & 1083 & $\pi(\mathrm{CH})+\pi(\mathrm{CN})$ \\
18 & $1100(62.4944)$ & $1104(84.5054)$ & 1012 & $\pi(\mathrm{SN})+\pi(\mathrm{CH})$ \\
20 & $1068(89.5381)$ & $1047(46.8724)$ & 962 & $\pi(\mathrm{CS})+\pi(\mathrm{CN})$ \\
21 & $994(0.4427)$ & $988(2.0534)$ & 924 & $\pi(\mathrm{CH})+\pi(\mathrm{CN})$ \\
22 & $850(34.5586)$ & $821(27.9594)$ & 844 & $\delta_{\text {ring }}$ \\
23 & $833(10.3135)$ & $806(11.074)$ & 830 & $\delta_{\text {ring }}$ \\
24 & $777(161.112)$ & $694(128.812)$ & 750 & $\delta_{\text {ring }}$ \\
\hline
\end{tabular}


Table 2. Continued

\begin{tabular}{ccccc}
\hline 25 & $716(138.28)$ & $685(25.8067)$ & 716 & $\delta_{\text {ring }}$ \\
26 & $638(251.059)$ & $617(0.5325)$ & 609 & $\delta\left(\mathrm{SO}_{2}\right)$ \\
27 & $586(92.7421)$ & $546(103.968)$ & 552 & $\delta_{\text {ring }}$ \\
29 & $514(4.1512)$ & $486(33.5871)$ & 479 & $\delta_{\text {ring }}$ \\
30 & $500(80.0976)$ & $481(54.5624)$ & 463 & $\delta\left(\mathrm{SO}_{2}\right)$ \\
31 & $453(2.5229)$ & $435(2.0194)$ & 448 & $\pi$ ring $+\omega\left(\mathrm{SO}_{2}\right)$ \\
\hline
\end{tabular}

$v$, stretching; $\delta$, in-plane bending; $\pi$, out of plane bending; $\omega$, wagging. Subscript: asym., asymmetric; sym., symmetric

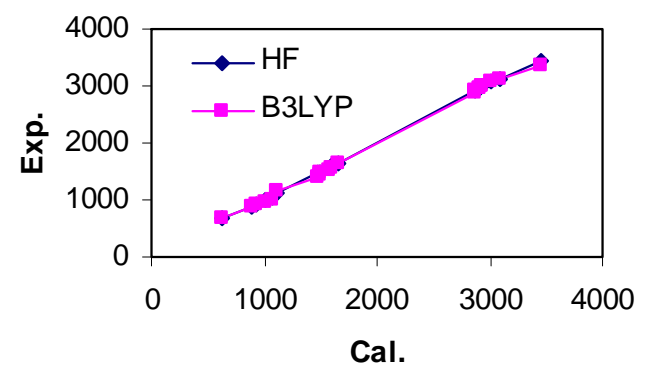

Figure 5. Graphic correlation between the experimental and the theoretical frequencies obtained by B3LYP/6-31G*method and $\mathrm{HF} / 6-31 \mathrm{G}^{*}$ method.

\section{Electronic absorption spectra}

Experimental electronic spectra measured in dichloromethane solution along with the theoretical electronic absorption spectra calculated on the B3LYP/6-31G* level optimized structure are listed in Table 3. In addition, the theoretical electronic spectra have a broad band from 304 to $308 \mathrm{~nm}$, which is different from the experimental peak at $312 \mathrm{~nm}$. Molecular orbital coefficients analyses based on the optimized geometry indicate that the frontier molecular orbitals are mainly composed of $p$ atomic orbitals, so electronic transitions corresponding to above electronic spectra are mainly LUMO and HOMO-LUMO for the title compound. Figure 6 shows the surfaces of HOMO (the highest occupied molecular orbital) and LUMO (the lowest unoccupied molecular orbital) So the electronic spectra are corresponding to electronic transition of the phenyl ring (transition of $\pi-\pi^{*}$ type). Absorption maxima $\left(\lambda_{\max }\right)$ for this compound were calculated by the CIS, TD, ZINDO methods.

Table 3. Experimental and theoretical electronic absorption spectra values

\begin{tabular}{|c|c|c|c|c|c|c|}
\hline \multirow[t]{2}{*}{ Exp } & \multicolumn{2}{|c|}{$\begin{array}{c}\text { Calculated } / \lambda_{\text {cal }}(\mathrm{nm}) \\
\text { CIS }\end{array}$} & \multicolumn{2}{|c|}{$\begin{array}{c}\text { Calculated } / \lambda_{\text {cal }}(\mathrm{nm}) \\
\text { TD }\end{array}$} & \multicolumn{2}{|c|}{$\begin{array}{c}\text { Calculated } / \lambda_{\text {cal }}(\mathrm{nm}) \\
\text { ZINDO }\end{array}$} \\
\hline & $\begin{array}{l}\text { oscillator } \\
\text { strength }\end{array}$ & $\begin{array}{c}\text { wave } \\
\text { length (nm) }\end{array}$ & $\begin{array}{c}\text { Oscillator } \\
\text { strength }\end{array}$ & $\begin{array}{c}\text { Wave } \\
\text { length }(\mathrm{nm})\end{array}$ & $\begin{array}{l}\text { Oscillator } \\
\text { strength }\end{array}$ & $\begin{array}{c}\text { Wave } \\
\text { length }(\mathrm{nm})\end{array}$ \\
\hline $\begin{array}{l}210,236, \\
310\end{array}$ & $\begin{array}{l}0.0676, \\
0.0000, \\
0.0002\end{array}$ & $\begin{array}{l}226.17, \\
285.49, \\
293.04\end{array}$ & $\begin{array}{l}0.0004 \\
0.0292 \\
0.4432\end{array}$ & $\begin{array}{l}305.29 \\
273.48 \\
268.52\end{array}$ & $\begin{array}{l}0.0002, \\
0.0000 \\
0.2312\end{array}$ & $\begin{array}{l}552.17 \\
459.62, \\
366.75\end{array}$ \\
\hline
\end{tabular}




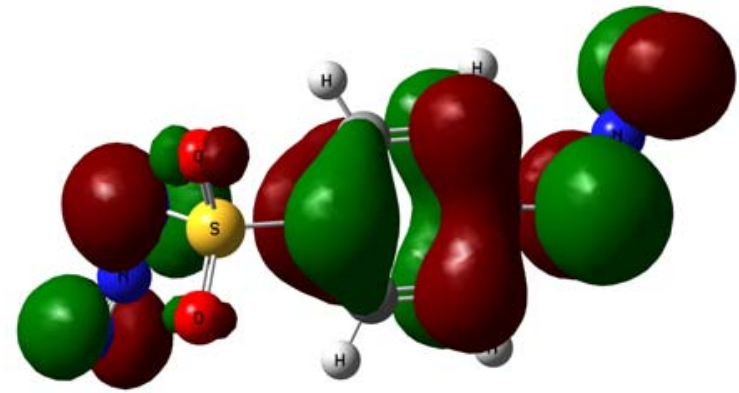

HOMO

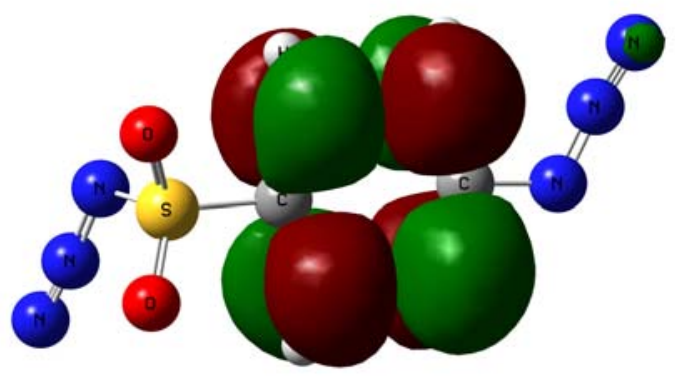

LUMO

Figure 6. Surfaces of HOMO, LUMO and HOMO-LUMO for the title compound.

\section{NMR spectra}

The experimental and theoretical values for ${ }^{1} \mathrm{H},{ }^{13} \mathrm{C}$ NMR, and calculated structural parameters of the title compound are given in Tables $4-5$. We have calculated the theoretical ${ }^{1} \mathrm{H},{ }^{13} \mathrm{C}$ NMR chemical shifts, and structural parameters of the title compound.

The theoretical ${ }^{1} \mathrm{H}$ and ${ }^{13} \mathrm{C}$ NMR chemical shifts of compound have been compared with the experimental data. According to these results, the calculated chemical shifts and coupling constants are in compliance with the experimental findings. In order to compare the experimental chemical shifts, the correlation graphics based on the calculations have been presented in Figure 7. The correlation values carbon and proton chemical shifts are found to be 0.9913 and 0.9919 for HF and B3LYP with the 6-31G* basis set, respectively.

Table 4. Experimental and calculated ${ }^{1} \mathrm{H}$ NMR chemical shifts (ppm) of the title compound

\begin{tabular}{cccc}
\hline Carbon & HF (TMS) & B3LYP (TMS) & Exp \\
\hline C2 & 148.827 & 131.28 & 146.85 \\
C3 & 124.697 & 107.193 & 129.42 \\
C4 & 132.386 & 114.783 & 120.57 \\
C5 & 145.987 & 128.453 & 133.04 \\
C6 & 134.121 & 116.565 & 120.57 \\
C7 & 123.098 & 128.514 & 129.42 \\
\hline
\end{tabular}

Table 5. Experimental and calculated ${ }^{13} \mathrm{C}$ NMR chemical shifts (ppm) of the title compound

\begin{tabular}{cccc}
\hline Poroton & HF (TMS) & B3LYP (TMS) & Exp \\
\hline H14 & 7.090 & 6.372 & 7.40 \\
H15 & 8.022 & 7.306 & 7.99 \\
H16 & 8.030 & 7.315 & 7.99 \\
H17 & 7.374 & 6.659 & 7.40 \\
\hline
\end{tabular}



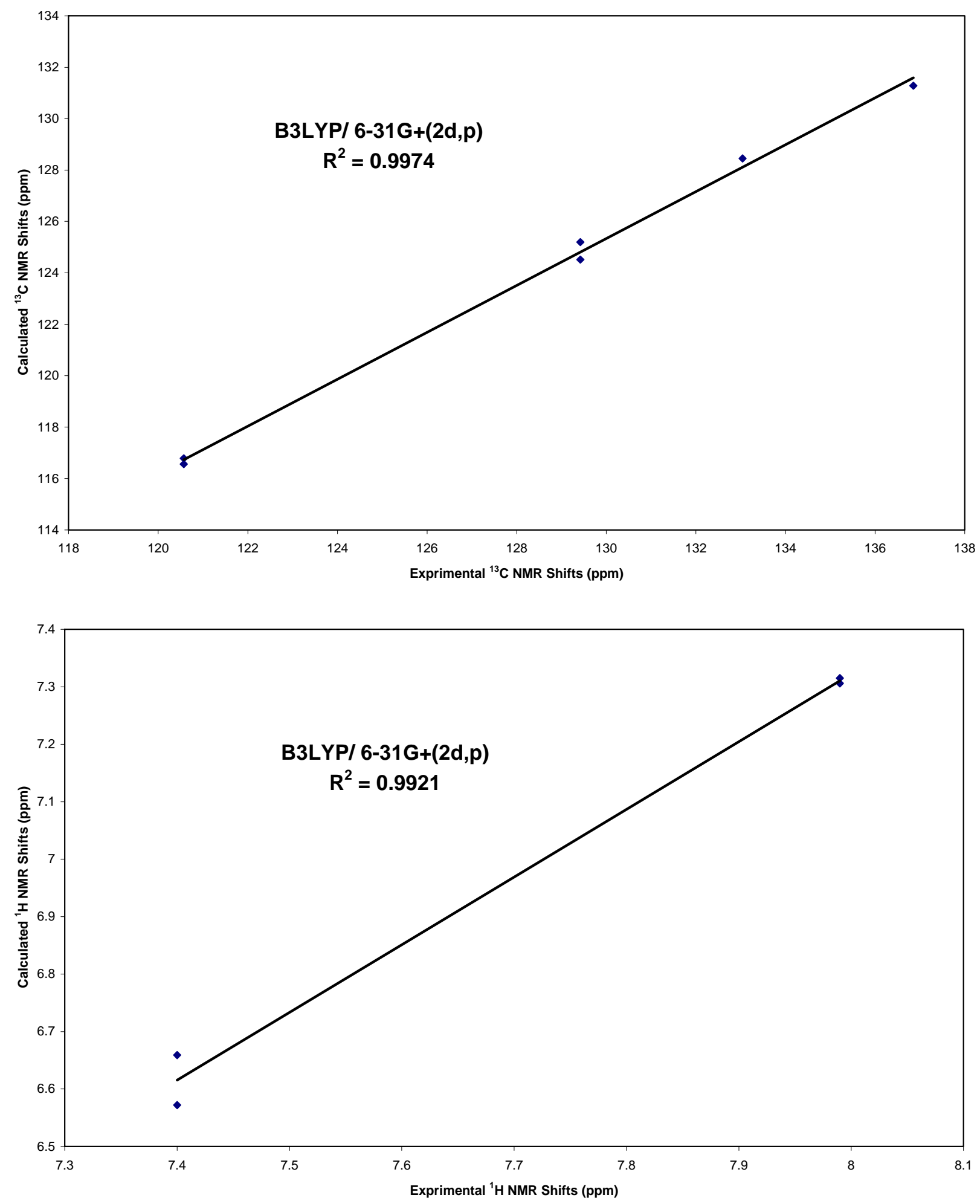

Figure 7. Plot of the calculated vs. the experimental ${ }^{13} \mathrm{C}$ NMR, ${ }^{1} \mathrm{H}$ NMR chemical shifts (ppm). 
As in Figure 8, this compound shows seven different carbon atoms, which is consistent with the structure on the basis of molecular symmetry. Due to that fact, in Figure 8, seven carbon peaks are observed in ${ }^{13} \mathrm{C}$ NMR spectrum of compound. If ${ }^{1} \mathrm{H}$ NMR spectrum (Figure 8 ) of the title compound is investigated, it can be seen that total number of protons are in agreement with the integration values presented in this spectrum. Chemical shifts were reported in ppm relative to TMS for ${ }^{1} \mathrm{H}$ and ${ }^{13} \mathrm{C}$ NMR spectra. ${ }^{1} \mathrm{H}$ and ${ }^{13} \mathrm{C}$ NMR spectra were obtained at a base frequency of $125.76 \mathrm{MHz}$ for ${ }^{13} \mathrm{C}$ and $500.13 \mathrm{MHz}$ for ${ }^{1} \mathrm{H}$ nuclei. Relative chemical shifts were then estimated by using the corresponding TMS shielding calculated in advance at the same theoretical level as the reference.

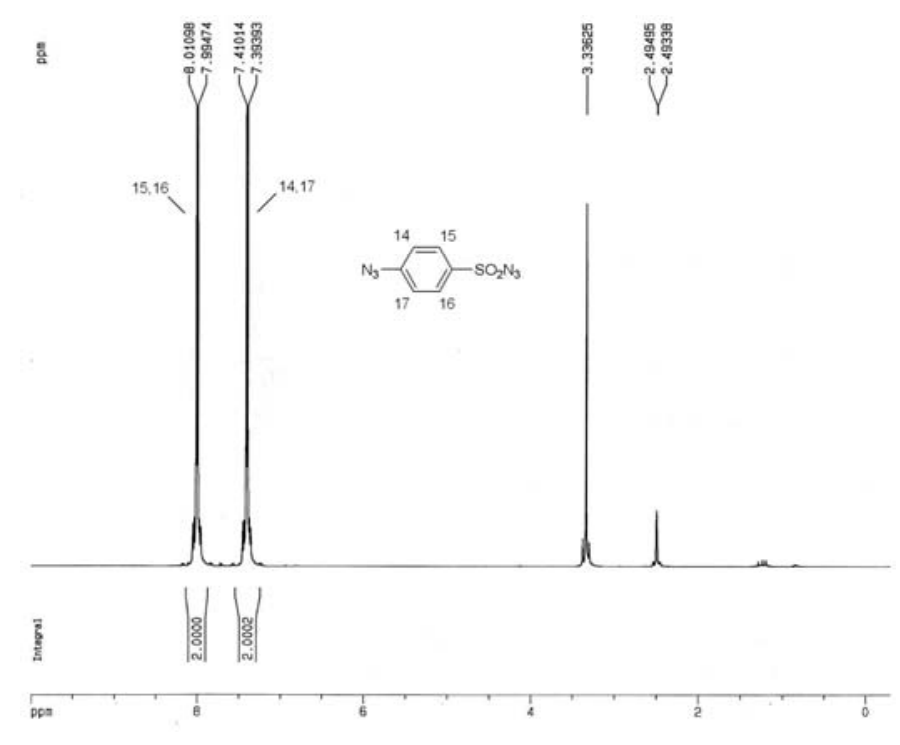

a

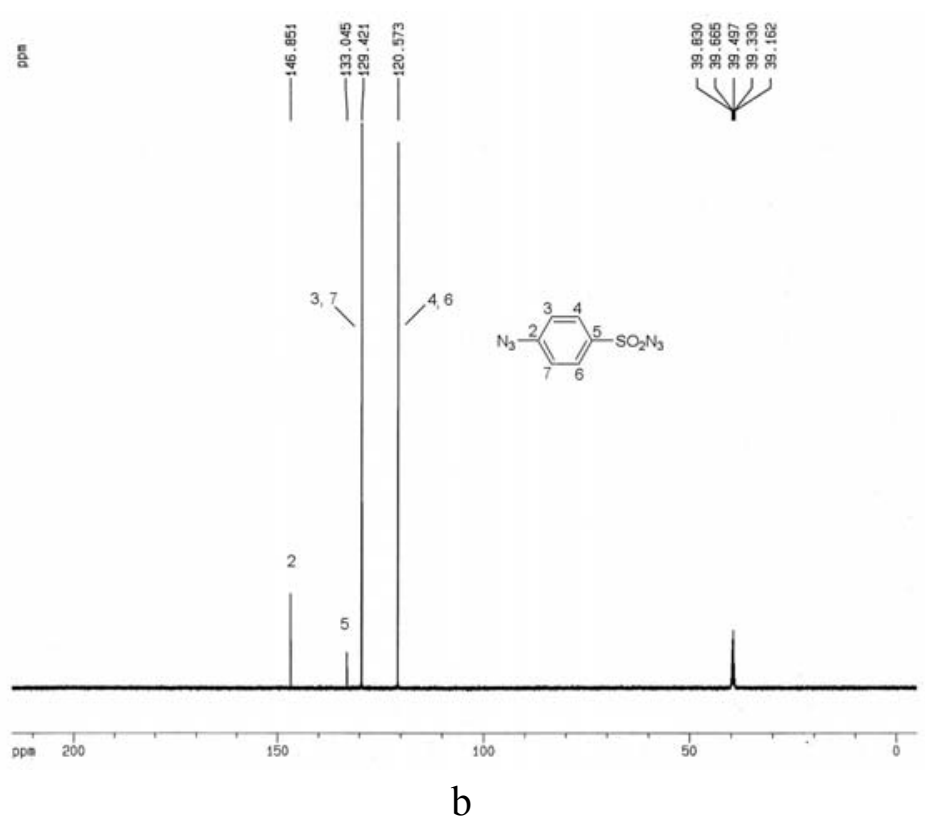

Figure 8. (a) ${ }^{1} \mathrm{H}$ NMR spectra, (b) ${ }^{13} \mathrm{C}$ NMR spectra of [4-(sulfonylazide)phenyl]-1-azide. 


\section{Thermodynamic properties}

On the basis of vibrational analyses and statistical thermodynamics, the standard thermodynamic functions: heat capacity $\left(\mathrm{C}_{p, m}^{\mathrm{o}}\right)$, entropy $S^{0}{ }_{m}$ and enthalpy $H^{\circ}{ }_{m}$ were obtained and listed in Table 6. Several calculated thermodynamic parameters are presented in Table 7. Scale factors have been recommended ${ }^{31}$ for an accurate prediction in determining the zero-point vibration energies and the entropy. The total energies and the change in the total entropy at room temperature at different methods are also presented.

Table 6. Thermodynamic properties at different temperatures at HF/6-31G* and B3LYP/6-31G* level

\begin{tabular}{ccccc}
\hline $\mathrm{T}\left(\mathrm{K}^{\circ}\right)$ & $\mathrm{C}^{\circ} \mathrm{p}, \mathrm{m}($ cal.mol-1K-1) & $\mathrm{S}^{\circ} \mathrm{m}($ cal.mol-1K-1) & $\begin{array}{c}\mathrm{H}^{\circ} \mathrm{m} \\
(\text { Kcal.mol-1) }\end{array}$ & $\begin{array}{c}\mathrm{G}^{\circ} \mathrm{p}, \mathrm{m} \\
(\text { Kcalmol-1) }\end{array}$ \\
\hline 100 & 13.364 & 69.643 & 71.112 & 64.148 \\
200 & 23.962 & 83.618 & 73.189 & 56.465 \\
300 & 33.648 & 95.990 & 76.273 & 47.476 \\
400 & 42.456 & 107.477 & 80.287 & 37.296 \\
500 & 49.868 & 118.218 & 85.114 & 26.006 \\
600 & 55.860 & 128.221 & 90.609 & 13.678 \\
700 & 60.692 & 137.514 & 96.644 & 0.385 \\
\hline
\end{tabular}

Table 7. Theoretically computed energies (a.u.), zero-point vibrational energies (kcal mol ${ }^{-1}$ ), rotational constants $(\mathrm{GHz})$, entropies $\left(\mathrm{cal} \mathrm{mol}{ }^{-1} \mathrm{~K}^{-1}\right)$ and dipole moment $(D)$ for the title compound

\begin{tabular}{ccc}
\hline Parameters & $\mathrm{HF} / 6-31 \mathrm{G}^{*}$ & $\mathrm{~B} 3 \mathrm{LYP} / 6-31 \mathrm{G}^{*}$ \\
\hline Total energy & -1103.2244023 & -1107.9881708 \\
Zero-point energy & 79.54400 & 73.19245 \\
Rotational constant & 1.42205 & 1.36829 \\
& 0.26537 & 0.25675 \\
Entropy & 0.25217 & 0.24494 \\
Total & & \\
Translational & 114.087 & 119.161 \\
Rotational & 42.122 & 42.122 \\
Vibrational & 32.491 & 32.591 \\
Dipole moment & 39.475 & 44.448 \\
\hline
\end{tabular}




\section{Conclusions}

[4-(Sulfonylazide)phenyl]-1-azide has been synthesized and characterized by elemental analysis, IR, UV-Vis DFT calculations at B3LYP/6-31G* level for compound show that the optimized geometry closely resemble the crystal structure. The comparisons between the calculated vibrational frequencies and the experimental IR spectra indicate they support each other. The predicted electronic absorption spectra have some blue shifts compared with the experimental data and molecular orbital coefficients analyses suggest that the electronic spectra are assigned to $\pi \rightarrow \pi^{*}$ electronic transitions. The experimental and the theoretical investigation of the title compound have been performed successfully by using NMR and quantum chemical calculations. Regarding the calculations, it is shown that the results of HF and B3LYP methods are in excellent agreement with all the experimental findings.

\section{Computational Methods}

The molecular structure of this compound in the ground state are also optimized by HF, Becke 3Lee-Yang-Parr (B3LYP) functionals ${ }^{32,33}$ and by combining the results of the GAUSSVIEW program.$^{24}$

Finally, the calculated normal mode vibrational frequencies (scaled by 0.8991 and 0.9663 for $\mathrm{HF} / 6-31 \mathrm{G}^{*}$ and B3LYP/6-31G*), the visible absorption maxima, NMR and thermodynamic properties were also calculated with these methods. These calculations were performed at Hartree-Fock (HF) and B3LYP levels on a Pentium IV/3.6 GHz personal computer using Gaussian $03 \mathrm{~W}^{31}$ program package. Initial geometries are obtained with PM3 method based on Hyperchem 7.02 package. $^{34}$

\section{Experimental Section}

General Procedures. Acetamidobenzenesulfonyl chloride was procured from Merck. Solvents were purchased from Merck. IR spectra were recorded on a JASCO FT/IR-680 PLUS spectrometer using $\mathrm{KBr}$ discs. NMR spectra were recorded on a Bruker 500 ultrasheild NMR and $\mathrm{CDCl}_{3}$ and DMSO- $\mathrm{d}_{6}$ were used as solvent. Mass spectra were determined on a Uk Fisons Trio 1000 spectrometer using electron impact at $70 \mathrm{eV}$. UV spectra were recorded on a JASCO V-570 UV/Vis/NIR spectrophotometer with some solvent. The elemental analysis was determined at the central laboratory, Isfahan University, Isfahan, Iran. The melting points were obtained on a Gallenkamp apparatus and are not corrected. Analytical TLC was performed on Silica Gel F254 plates (Merck) and for column chromatography Merck silica gel 60 (40-63 $\mu$ 230-400 ASTM) was used. 
Synthesis of 4-acetamidobenzenesulfonyl azide. Acetamidobenzenesulfonyl chloride ( $48.6 \mathrm{~g}$, $208 \mathrm{mmol}$ ) was dissolved in $500 \mathrm{ml}$ acetone and the solution was cooled to temperature of $0{ }^{\circ} \mathrm{C}$ over a period of $60 \mathrm{~min}$. A chilled aqueous solution of sodium azide (20 g, $312 \mathrm{mmol}, 200 \mathrm{ml})$ was added dropwise and the resultant solution allowed to stir for a further $60 \mathrm{~min}$ at that temperature. The solution was then poured onto an ice/water slurry $(1.5 \mathrm{~L})$ and the white precipitate was collected at the pump, washed with ice-cold water and dried under vacuum, 4Acetamidobenzenesulfonyl azide could be used in the next step directly, recrystallized from a solution of acetone and water giving 4-Acetamidobenzenesulfonyl azide as white crystals, Yield: 75\%; m.p. 108-110 ${ }^{\circ} \mathrm{C}$; (Ref. ${ }^{35} 113-114{ }^{\circ} \mathrm{C}$ ); Analysis: calcd. C 40.01, H $3.36 \mathrm{~N} 23.32$; found C 39.86, H 3.26, 23.22. ${ }^{1} \mathrm{H}$ NMR (DMSO- $\left.d_{6}\right): \delta(\mathrm{ppm}): 8.4(1 \mathrm{H}, \mathrm{s}, \mathrm{NH}), 7.82(\mathrm{H}, \mathrm{d}, J=8.3 \mathrm{~Hz}$, phenyl), $2.23\left(3 \mathrm{H}, \mathrm{s}, \mathrm{CH}_{3}\right) ;{ }^{13} \mathrm{C}$ NMR (DMSO- $\left.d_{6}\right): \delta(\mathrm{ppm}): 169.5,144.1,132.3,128.9,119.6$, 24.7; FTIR (KBr) 2125, 1674, $1160 \mathrm{~cm}^{-1} ; m / z 240\left(\mathrm{C}_{8} \mathrm{H}_{8} \mathrm{~N}_{4} \mathrm{O}_{3} \mathrm{~S}\right)$.

Synthesis of [4-(Sulfonyazide)phenyl]-1-azide. Acetamidobenzenesulfonyl azide (2.4 g, 10 $\mathrm{mmol}$ ) and $10 \mathrm{~mL}$ concentrated $\mathrm{HCl}$ wwere heated at reflux for $35 \mathrm{~min}$, the resulting solution was cooled in an ice/salt bath to $0{ }^{\circ} \mathrm{C}$. The solution was diazotized with a solution of sodium nitrite $(0.76 \mathrm{~g}, 11 \mathrm{mmol})$ in water $(20 \mathrm{~mL})$, with the temperature maintained below $5{ }^{\circ} \mathrm{C}$, and then stirred for a further $30 \mathrm{~min}$ in the cold. The solution was then neutralized with a saturated sodium bicarbonate solution. Sodium azide $(15 \mathrm{mmol})$ in water $(15 \mathrm{~mL})$, was added slowly to a stirred suspension of $(10 \mathrm{mmol})$ diazonium salt. After stirring for an additional $30 \mathrm{~min}$, the mixture was further neutralized with a saturated sodium carbonate solution and then left to stir until precipitation was deemed to be complete $(2-3 \mathrm{~h})$. The solid product was filtered under suction, dried, and recrystallized from petroleum ether-dichloromethane give white-yellow solid. Yield: $65 \%$; m.p. $37-39^{\circ} \mathrm{C}$ [Ref. ${ }^{36} 31-33{ }^{\circ} \mathrm{C}$ ]; Analysis: calcd. C 32.14, H $1.80 \mathrm{~N} 37.48$; found C 32.06, H 1.68, 37.26. ${ }^{1} \mathrm{H}$ NMR (DMSO- $\left.d_{6}\right): \delta(\mathrm{ppm}): 7.99\left(2 \mathrm{H}, \mathrm{d}, J=8.12 \mathrm{~Hz}, \mathrm{H}_{15}, \mathrm{H}_{16}\right) ; 7.40$ $\left(1 \mathrm{H}, \mathrm{d}, J=8.10, \mathrm{H}_{14}, \mathrm{H}_{17}\right) ;{ }^{13} \mathrm{C}$ NMR (DMSO- $\left.d_{6}\right): \delta(\mathrm{ppm}): 146.85$, $1 \mathrm{C}\left(\mathrm{C}_{2}\right) ; 133.04,1 \mathrm{C}\left(\mathrm{C}_{5}\right)$; $129.42,2 \mathrm{C}\left(\mathrm{C}_{3}, \mathrm{C}_{7}\right)$; 120.57, 2C $\left(\mathrm{C}_{4}, \mathrm{C}_{6}\right)$; FTIR (KBr) 3092, 2323, 2256, 2129, 1582, 1366, $1169,830,750,609 \mathrm{~cm}^{-1} ; m / z 224\left(\mathrm{C}_{6} \mathrm{H}_{4} \mathrm{~N}_{6} \mathrm{O}_{2} \mathrm{~S}\right)$

\section{Acknowledgements}

Support from the Yasouj University (YU) research council and help of Payame Noor University in Isfahan are gratefully acknowledged. The authors wish to thank Mr. M. Kamali for the help in the elemental analysis.

\section{References}

1. (a) Carey, F. A.; Sundberg, R. J.; Advanced Organic Chemistry, Part A: Structure and Mechanisms, $4^{\text {th }}$ Edn. Kluwer: New York, 2000; p 646. (b) Scriven, E. F. V. Ed., Azides and 
Nitrenes: Reactivity and Utility, Chap. 4, Academic Press New York, 1984; p 205. (c) Padwa, A. Edn., 1,3-Dipolarcycloaddition Chemistry, Chap. 5, Wiley: New York, 1985; p 559.

2. (a) Kumar, R. R.; Perumal, S.; Kagan, H. B.; Guillot, R. Tetrahedron 2006, 62, 12380. (b) Kalita, P. K.; Baruah, B.; Bhuyan, P. J. Tetrahedron Lett. 2006, 47, 7779 (c) Sibi, M. P.; Stanley, L. M.; Soeta, T. Adv. Syn. Catal. 2006, 348, 2371. (d) Choi, W. J.; Shi, Zh. D.; Worthy, K. M.; Bindu,. L.; Karki, R. G.; Nicklaus, M. C.; Fisher, R. J.; Burke, T.R. Bioorg. Med. Chem. Lett. 2006, 16, 5262. (e) Jorgensen, J. K.; Ommundsen, E.; Stori, A.; Redford, K. Polymer 2005, 46, 12073.

3. Breslow, D. S.; Spurlin, H. M. US Pat. 3203937, 1965.

4. Terbrueggen, R. H.; Drumright, R. E. World Pat. $2000052091,2000$.

5. Machado, M.; Kenny, J. M. Rubber. Chem Tech. 2001, 74, 198.

6. Gonzalez, J. L. B.; Rueda, L. M. I.; Hernandez, L.G. Kautsch Gummi Kunstst. 1990, 43, 697.

7. Gonzalez, H. L.; Rodriguez, D. A.; Gonzalez, D. B. Rubber Chem Tech 1992, 65, 869.

8. Wigley, D. E. In Karlin, K. D. Ed., Progress in Inorganic Chemistry, Vol. 42; Wiley: New York, 1994; p 239.

9. (a) Proulx, G.; Bergman, R. G. J. Am. Chem. Soc. 1995, 117, 6382. (b) Fickes, M. G.; Davis, W. M.; Cummins, C. C. J. Am. Chem. Soc. 1995, 117, 6384.(c) Hanna, T. A.; Baranger, A. M.; Bergman, R. G. Angew. Chem. Int. Ed. 1996, 35, 653. (d) Barz, M.; Herdtweck E.; Thiel, W. R. Angew. Chem. Int. Ed. 1998, 37, 2262. (e) Foch I.; Parkanyi L.; Besenyei, G.; Simandi, L. I.; Kalman, A. J. Chem. Soc., Dalton Trans. 1999, 293. (f) Besenyei, G.; Parkanyi, L.; Foch, I.; Simandi, L. I.; Angew. Chem. Int. Ed. 2000, 39, 956. (g) Dias, H. V. R.; Polach, S. A.; Goh, S.; Archibong, E. F.; Marynick, D. S. Inorg. Chem. 2000, 39, 3894.

10. (a) Magan Kanjia, D.; Mason, J.; Stenhouse, I. A.; Banks, R. E.; Venayak, N. D. J. Chem. Soc., Perkin Trans. 1 1981, 975. (b) Dahn, H.; Toan, V. V.; Pechy, P. Magn. Reson. Chem. 1995, 33, 686.

11. Heineking, N.; Gerry, M. C. L. Z. Naturforschung A 1989, 669.

12. Haist, R.; Mack, H. G.; Della Vedova, C. O.; Cutın, E.H.; Oberhammer, H. J. Mol. Struct. 1998, 445, 197.

13. Fraser, R. T. M.; Paul, N. C.; Bagley, M. J. Org. Mass Spectrom. 1973, 7, 83.

14. (a) Sklenak, S.; Gatial, A.; Biskupic, S. J. Mol. Struct. (Theochem) 1997, 397, 249. (b) Parkanyi, L.; Besenyei, G. Journal of Molecular Structure 2004, 691, 97.

15. Hernandez, L.G.; Diaz, A.R.; Gonzalez, J.L.B. Rubber Chem. Tech. 1992, 65, 869-78.

16. Borve, K. L.; Redford K.; Stori, A. World Patent 2003020815, 2003.

17. Borve, K. L.; Redford, K.; Skattum, M. Haavaldsen. World Patent 2001066632, 2001.

18. Dabbagh, H. A.; Teimouri, A.; Chermahini, A. N. Spectrochimica Acta 2006; Part A 67, 437.

19. Dabbagh, H. A.; Teimouri, A.; Chermahini, A. N. Spectrochimica Acta 2008; Part A 69, 449.

20. Dabbagh, H. A.; Teimouri, A.; Chermahini, A. N. Dyes and Pigments 2007, 73, 239.

21. Dabbagh, H. A.; Teimouri, A.; Chermahini, A. N. Applied Catalysis B: Environmental 2007, $76,24$. 
22. Parkanyi, L.; Besenyei, G. J. Mol. Struct. 2004, 691, 97.

23. Altun, A.; Golcuk, K.; Kumru, M. J. Mol. Struct: THEOCHEM 2003, 637, 155.

24. Frisch, A., Nielsen, A. B. Holder, A. J. Gaussview Users Manual, Gaussian Inc, 2003.

25. (a) Radom, L.; Pople, J. A. J. Am. Chem. Soc. 1970, 92, 4786. (b) Pople, J. A.; Schlegel, H. B.; Krishnan, R.; Defrees, D. J.; Binkley, J. S.; Frisch, M. J.; Whiteside, R. A.; Hout, R. H.; Hehre, W. J. Int. J. Quant. Chem. Quant. Chem. Symp. 1981, 15, 269. (c) Pople, J. A.; Scolt, A. P.; Wong, M. W.; Radom, L. Instrum. J. Chem. 1993, 33, 345.

26. Ap, S.; Radom, L. J. Phys. Chem. 1996, 100, 16502.

27. Sing, N. D.; Yadav, R. A. Ind. J. Phys. 2001, 75, 347.

28. Rastogi, K.; Palafox, M. A.; Tanwar, R. P.; Mittal, L. Spectrochim. Acta 2002, 58, 1989.

29. Silverstein, M.; Basseler, G. C.; Morill, C. Spectrometric Identification of Organic Compounds, Wiley: New York, 1981.

30. Roegers, P. G., A Guide to the Complete Interpretation of Infrared Spectra of Organic Structures, Wiley: Canada, 1994.

31. Frisch, M. J.; Trucks, G. W.; Schlegel, H. B.; Scuseria, G. E.; Robb, M. A.; Cheeseman, J. R.; Montgomery, J. A., Jr.; Vreven, T.; Kudin, K. N.; Burant, J. C.; Millam, J. M.; Iyengar, S. S.; Tomasi, J.; Barone, V.; Mennucci, B.; Cossi, M.; Scalmani, G.; Rega, N.; Petersson, G. A.; Nakatsuji, H.; Hada, M.; Ehara, M.; Toyota, K.; Fukuda, R.; Hasegawa, J.; Ishida, M.; Nakajima, T.; Honda, Y.; Kitao, O.; Nakai, H.; Klene, M.; Li, X.; Knox, J. E.; Hratchian, H. P.; Cross, J. B.; Bakken, V.; Adamo, C.; Jaramillo, J.; Gomperts, R.; Stratmann, R. E.; Yazyev, O.; Austin, A. J.; Cammi, R.; Pomelli, C.; Ochterski, J. W.; Ayala, P. Y.; Morokuma, K.; Voth, G. A.; Salvador, P.; Dannenberg, J. J.; Zakrzewski, V. G.; Dapprich, S.; Daniels, A. D.; Strain, M. C.; Farkas, O.; Malick, D. K.; Rabuck, A. D.; Raghavachari, K.; Foresman, J. B.; Ortiz, J. V.; Cui, Q.; Baboul, A. G.; Clifford, S.; Cioslowski, J.; Stefanov, B. B.; Liu, G.; Liashenko, A.; Piskorz, P.; Komaromi, I.; Martin, R. L.; Fox, D. J.; Keith, T.; Al-Laham, M. A.; Peng, C. Y.; Nanayakkara, A.; Challacombe, M.; Gill, P. M. W.; Johnson, B.; Chen, W.; Wong, M. W.; Gonzalez, C.; Pople, J. A. Gaussian 03, Revision C.02; Gaussian: Wallingford CT, 2004.

32. Becke, A. D. J. Chem. Phys. 1993, 98, 5648.

33. Lee, C.; Yang W.; Parr, R.G. Phys. Rev. B 1998, 37, 785.

34. HyperChem 7.02, Hypercube, Inc, 2002.

35. Griffiths. J.; Mcdarmaid. R. I. J. S. D. C. 1977, 93, 455.

36. Sauer, E.; Bendig, J.; Heutzenroeder, K. J. Prak. Chem. 1988, 330, 492. 